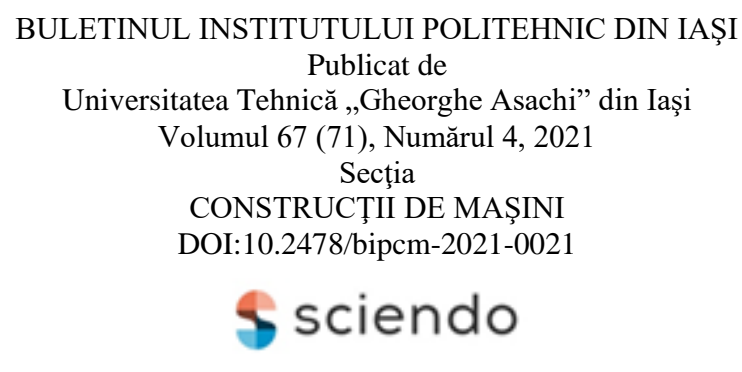

\title{
A METHOD TO FIND THE DIFFERENTIAL EQUATIONS FROM THE BOND GRAPH CONTAINING INERTIAL ELEMENTS IN DERIVATIVE CAUSALITY
}

BY

\author{
RADU IBĂNESCU ${ }^{1, *}$ and MIHAELA IBĂNESCU ${ }^{2}$ \\ "Gheorghe Asachi "Technical University of Iași, \\ Faculty of Machine Manufacturing and Industrial Management \\ "Gheorghe Asachi "Technical University of Iași, \\ Faculty of Civil Engineering and Building Services
}

Received: November 27, 2021

Accepted for publication: December 7, 2021

Abstract. The bond-graph method is used for finding the equations which describe the systems dynamics, by analysing the way of power transmission from the source to the working elements. When the energy storage elements I and C are in integral causality, the number of state equations equals the number of these elements. If there are also energy storage elements in derivative causality, the system contains a number of differential equations equal to the number of energy storage elements in integral causality and a number of algebraic equations equal to the number of energy storage elements in derivative causality. The work presents a new method for finding the system of differential equations for mechanical systems with one degree of freedom, starting from the original system which contains both algebraic and differential equations. energy.

Keywords: system dynamics; bond graph; derivative causality; kinetic

\footnotetext{
*Corresponding author e-mail: ribanesc@yahoo.com.

(C) 2021 Radu Ibănescu et al.

This is an open access article licensed under the Creative Commons Attribution-NonCommercialNoDerivatives 4.0 International License (CC BY-NC-ND 4.0).
} 


\section{Introduction}

The bond-graph method has been discovered by Henry Painter, who wrote the first book about it (Paynter, 1961). The method had a very widespread because of its simplicity and orientation more towards the engineering aspect than to the mathematical tools, like Lagrange equations (Ibănescu and Ungureanu, 2015). The method has been approached in many books and articles such as (Karnopp, 1992; Păstrăvanu and Ibănescu, 2001; Borutzky, 2010; Karnopp, 2012; Lagnier et al., 2016; Ibănescu, 2017). These and many others are important contributions in the development of the method performances and in the extension of its fields of application (mechanical, electrical, hydraulic, magnetic etc.).

This paper presents a new path for obtaining the state equations in case of a bond-graph model which contains inertial energy storage elements (I) in differential causality.

\section{Problem Presentation}

When the bond-graph model contains only energy storage elements in integral causality, the number of derived state equations is the same with the number of these elements. When the model also contains energy storage elements in derivative causality, the number of differential equations equals the number of energy storage elements in integral causality and a number of algebraic equations which is the same with the number of energy storage elements in derivative causality. So, the resulted system of equations is an algebraic-differential one.

This system should be transformed into a system of differential equations, whose number must coincide with the number of energy storage elements in integral causality contained by the bond-graph model. The system of equations, under this new form, could be easily numerically integrated.

The system of differential equations is usually obtained by differentiating the algebraic equations and by substituting these derivatives in the system differential equations. This system is put in its explicit form, in view of its numerical integration.

The work presents a new possible method for deducing the differential equations in case of mechanical systems with one degree of freedom. It presumes the calculus of the kinematic energy of the entire system, instead of differentiating the algebraic equations. As the system has a single degree of freedom, an independent position parameter is chosen, which corresponds to the unique element I in integral causality.

The kinematic energy is expressed only in terms of the chosen parameter, by using the connection equations. Then, the kinetic energy expression is differentiated with respect to time. As the derivative of the kinetic energy with respect to time equals the power, it can be point out that the derivative represents 
the product between an expression and the derivative of the independent position parameter with respect to time.

The expression has units of measuring for forces $[\mathrm{N}]$, and it is called inertia total force, if the position parameter is a linear displacement, or units of measuring for moments $[\mathrm{Nm}]$, when the position parameter is an angular displacement, and it is called inertia total moment.

On the other side, the differential equation, corresponding to the derivative of the independent position parameter, obtained according to the bondgraph method, will have in the left member, after substituting the derivatives of the algebraic equations, exactly the expression of the inertial total force or of the inertial total moment.

\section{Study Case}

A plane mechanical system with one degree of freedom is considered (Fig. 1). It consists of a bar (2), of length $2 l$ and mass $M_{2}$, pinned at one end to a link box (1) of mass $M_{1}$ and a disk (3) of mass $M_{3}$ and radius $R$.

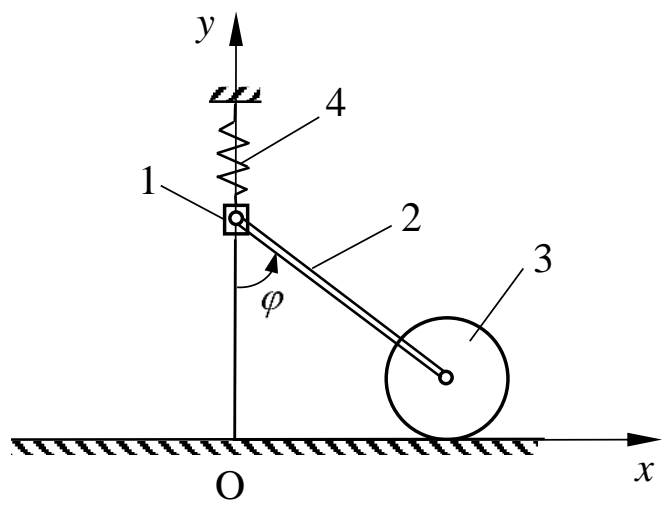

Fig. 1 - The mechanical system.

The disk is rolling without slipping along a horizontal straight line.

The link box (1) is attached to a vertical spring, having the stiffness $k$ and it can move only along the vertical direction.

When the bar has a vertical position, the spring is unstressed, which means that the elastic force is zero.

The single independent position parameter is angle $\varphi$, between the bar and the vertical direction.

The centroids of the component parts of the system are denoted by $G_{1}, G_{2}$ and $G_{3}$. For finding the bond-graph model, but also the kinetic energy expression, the connection equations and their derivatives with respect to time are needed. 


$$
\begin{gathered}
x_{G_{1}}=0 \\
y_{G_{1}}=R+2 l \cos \varphi \\
x_{G_{2}}=l \sin \varphi \\
y_{G_{2}}=R+l \cos \varphi \\
x_{G_{3}}=2 l \sin \varphi \\
y_{G_{3}}=R \\
\dot{x}_{G_{1}}=0 \\
\dot{y}_{G_{1}}=-2 l \dot{\varphi} \sin \varphi \\
\dot{x}_{G_{2}}=l \dot{\varphi} \cos \varphi \\
\dot{y}_{G_{2}}=-l \dot{\varphi} \sin \varphi \\
\dot{x}_{G_{3}}=2 l \dot{\varphi} \cos \varphi \\
\dot{y}_{G_{3}}=0
\end{gathered}
$$

The system bond-graph model is presented in Fig.2.

The following system of algebraic-differential equations is obtained for the bondgraph model:

$$
\begin{gathered}
\dot{p}_{10}=-\dot{p}_{13} l \cos \varphi+\dot{p}_{9} 2 l \sin \varphi-\dot{p}_{16} 2 i \cos \varphi-\dot{p}_{19} \frac{2 l \cos \varphi}{R}+ \\
+\dot{p}_{1} l \sin \varphi+M_{1} g 2 l \sin \varphi+M_{2} g l \sin \varphi+k q_{7} 2 l \sin \varphi \\
\dot{q}_{7}=-\frac{6 \sin \varphi}{M_{2} l} p_{10} \\
p_{13}=\frac{3 \cos \varphi}{l} p_{10}
\end{gathered}
$$




$$
\begin{gathered}
p_{9}=-\frac{6 M_{1}}{M_{2} l} \sin \varphi p_{10} \\
p_{16}=\frac{6 M_{3}}{M_{2} l} \cos \varphi p_{10} \\
p_{16}=\frac{3 M_{3} R}{M_{2} l} \cos \varphi p_{10} \\
p_{1}=-\frac{3 \sin \varphi}{l} p_{10}
\end{gathered}
$$

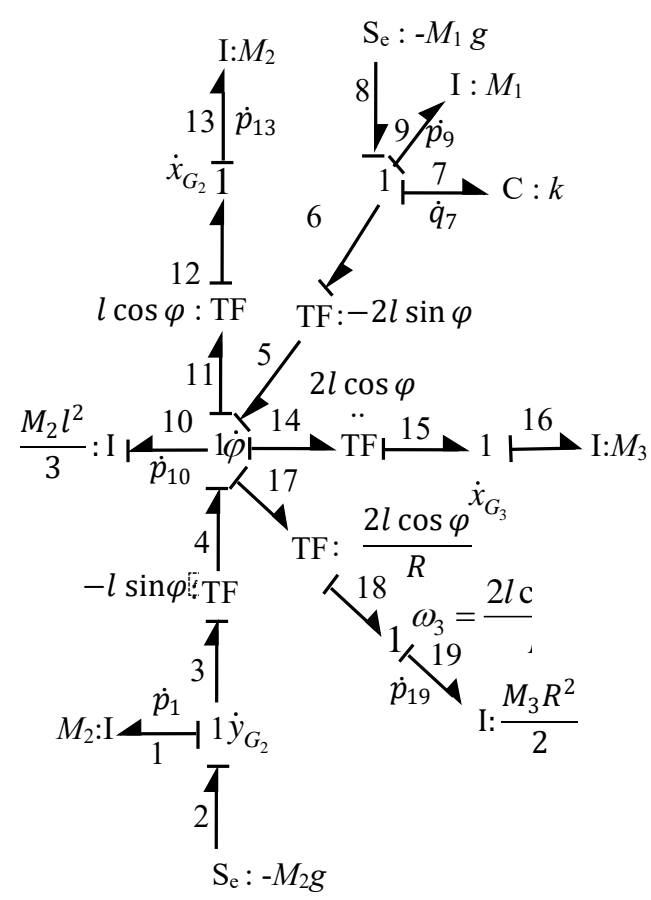

Fig. 2 - The bond graph model.

To transform the $\mathrm{Eq}(13)$ into a differential equation, whose unknowns are $\varphi$ and $q_{7}$, the Eq. (14), Eq. (15), Eq. (16), Eq. (17), Eq. (18) and Eq. (19) are differentiated with respect to time.

$$
\text { It is obtained: }
$$




$$
\begin{gathered}
\dot{p}_{13}=-\frac{9 \sin \varphi}{M_{2} l^{3}} p_{10}^{2}+\frac{3 \cos \varphi}{l} \dot{p}_{10} \\
\dot{p}_{9}=-\frac{18 M_{1} \cos \varphi}{M_{2}^{2} l^{3}} p_{10}^{2}-\frac{6 M_{1} \sin \varphi}{M_{2} l} \dot{p}_{10} \\
\dot{p}_{9}=-\frac{18 M_{3} \sin \varphi}{M_{2}^{2} l^{3}} p_{10}^{2}+\frac{6 M_{3} \cos \varphi}{M_{2} l} \dot{p}_{10} \\
\dot{p}_{19}=-\frac{9 M_{3} R \sin \varphi}{M_{2}^{2} l^{3}} p_{10}^{2}+\frac{3 M_{3} R \cos \varphi}{M_{2} l} \dot{p}_{10} \\
\dot{p}_{1}=-\frac{9 \cos \varphi}{M_{2} l^{3}} p_{10}^{2}-\frac{3 \sin \varphi}{l} \dot{p}_{10}
\end{gathered}
$$

where, it has been considered that

$$
\dot{\varphi}=\frac{3}{M_{2} l^{2}} p_{10} .
$$

The derivatives are replaced in Eq. (13) and the following differential equation is determined:

$$
\begin{aligned}
\dot{p}_{10}(4 & \left.+\frac{12 M_{1}}{M_{2}} \sin ^{2} \varphi+\frac{18 M_{3}}{M_{2}} \cos ^{2} \varphi\right)=\left(-\frac{36 M_{1}}{M_{2}^{2} l^{2}}+\frac{54 M_{3}}{M_{2}^{2} l^{2}}\right) \sin \varphi \cos \varphi p_{10}^{2}+ \\
& +M_{1} g 2 l \sin \varphi+M_{2} g l \sin \varphi+k q_{7} 2 l \sin \varphi
\end{aligned}
$$

The derivative with respect to time of Eq. (25) leads to:

$$
\ddot{\varphi}=\frac{3}{M_{2} l^{2}} \dot{p}_{10}
$$

And from Eq. (25) and Eq. (27) it results:

$$
p_{10}=\frac{M_{2} l^{2}}{3} \dot{\varphi} \quad \dot{p}_{10}=\frac{M_{2} l^{2}}{3} \ddot{\varphi} .
$$

By substituting Eq. (28) in Eq. (26), the following differential equation results: 


$$
\begin{gathered}
\left(4 M_{1} l^{2} \sin ^{2} \varphi+\frac{4}{3} M_{2} l^{2}+6 M_{3} l^{2} \cos ^{2} \varphi\right) \ddot{\varphi}+\left(4 M_{1}-6 M_{3}\right) l^{2} \sin \varphi \cos \varphi \dot{\varphi}^{2}= \\
=M_{1} g 2 l \sin \varphi+M_{2} g l \sin \varphi+k q_{7} 2 l \sin \varphi
\end{gathered}
$$

The previous equation and the equation

$$
\dot{q}_{7}=-2 l \sin \varphi \dot{\varphi}
$$

(which results from Eq. (14), by using Eq. (28)), represents a system of two differential equations, where $q_{7}$ is the spring elongation.

Another possibility of obtaining the left member of Eq. (28) consists in computing the system kinetic energy and in its differentiation with respect to time.

The system kinematic energy is:

$$
E=\frac{1}{2} M_{1} v_{G_{1}}^{2}+\frac{1}{2} M_{2} v_{G_{2}}^{2}+\frac{1}{2} J_{2} \omega_{2}^{2}+\frac{1}{2} M_{3} v_{G_{3}}^{2}+\frac{1}{2} J_{3} \omega_{3}^{2}
$$

where $v_{G_{1}}, v_{G_{2}}$ and $v_{G_{3}}$ are the bodies 1,2 and 3 center of mass velocities, $\omega_{2}$ and $\omega_{3}$ are the bodies 2 and 3 angular velocities and

$$
J_{2}=\frac{M_{2} l^{2}}{3} \text { and } J_{3}=\frac{M_{3} R^{2}}{2}
$$

are their moments of inertia with respect to their center of mass.

From the Eq. (7), Eq. (8), Eq. (9), Eq. (10), Eq. (11) and Eq. (12) it is obtained

$$
\begin{gathered}
v_{G_{1}}^{2}=4 l^{2} \sin ^{2} \varphi \dot{\varphi}^{2} \\
v_{G_{2}}^{2}=l^{2} \dot{\varphi}^{2} \\
v_{G_{3}}^{2}=4 l^{2} \cos ^{2} \varphi \dot{\varphi}^{2}
\end{gathered}
$$

where $\dot{\varphi}$ is the angular velocity $\omega_{2}$.

As the disk rolls without slipping, it results: 


$$
\omega_{3}=\frac{v_{G_{3}}}{R}
$$

so

$$
\omega_{3}^{2}=\frac{4 l^{2} \cos ^{2} \varphi}{R^{2}} \dot{\varphi}^{2} .
$$

After substitutions, the kinetic energy expression, in terms of $\dot{\varphi}$, results in the following form:

$$
E=2 M_{1} l^{2} \sin ^{2} \varphi \dot{\varphi}^{2}+\frac{2}{3} M_{2} l^{2} \dot{\varphi}^{2}+3 M_{3} l^{2} \cos ^{2} \varphi \dot{\varphi}^{2}
$$

The derivative of the kinetic energy with respect to time is:

$$
\begin{gathered}
\dot{E}=\left[\left(4 M_{1} l^{2}-6 M_{3} l^{2}\right) \sin \varphi \cos \varphi \dot{\varphi}^{2}+\right. \\
\left.\left(4 M_{1} l^{2} \sin ^{2} \varphi+\frac{4}{3} M_{2} l^{2}+6 M_{3} l^{2} \cos ^{2} \varphi\right) \ddot{\varphi}\right] \dot{\varphi}
\end{gathered}
$$

The term in the bracket is a moment, according to the units of measuring, and will be called inertia total moment, denoted $M_{I}$, because it is originated from the bond graph inertial elements. Eq. (39) can be written:

$$
\dot{E}=M_{I} \dot{\varphi}
$$

The inertial total moment $M_{I}$ expression coincides with the left member of Eq. (29).

If Eq. (13) is written so that in the left member to have only terms which contain the derivatives of generalized momenta for all elements I of the system, it is obtained:

$$
\begin{gathered}
\dot{p}_{10}+\dot{p}_{13} l \cos \varphi-\dot{p}_{9} 2 l \sin \varphi+\dot{p}_{16} 2 i \cos \varphi+\dot{p}_{19} \frac{2 l \cos \varphi}{R}-\dot{p}_{1} l \sin \varphi= \\
=M_{1} g 2 l \sin \varphi+M_{2} g l \sin \varphi+k q_{7} 2 l \sin \varphi
\end{gathered}
$$

The right member of Eq. (41) coincides with the right member of Eq. (29). As the left member of Eq. (29) is quite the inertial total moment $M_{I}$, it means that Eq. (41) could be written:

$$
M_{I}=M_{1} g 2 l \sin \varphi+M_{2} g l \sin \varphi+k q_{7} 2 l \sin \varphi
$$


As a conclusion, by using the derivative with respect to time of the system kinetic energy, from Eq. (13) written in the form of Eq. (41), the Eq. (29) is much easily obtained. The calculus volume is much more reduced, because to compute the derivatives of the dependent variables and to substitute them in Eq. (13) is more difficult than to compute the derivative of the kinetic energy which leads to $M_{I}$, that is the left member of the Eq. (41).

\section{Conclusions}

The bond-graph method for solving system dynamics problem leads to a system of algebraic-differential equations when the model contains inertial elements in derivative causality.

This system can be transformed into a system of only differential equations, by differentiating the algebraic equations and substituting them in the existing differential equations.

This operation presumes a great work volume.

The present paper proposes an easier method for obtaining the system of differential equations in case of systems with one degree of freedom.

The method is based on the calculus of the system kinetic energy derivative with respect to time.

\section{REFERENCES}

Borutzky W., Bond Graph Methodology. Development and Analysis of MultiDisciplinary Dynamic System Models, Springer-Verlag, London, 2010.

Ibănescu R., Ungureanu C., Lagrange's Equations versus Bond Graph Modeling Methodology by an Example of a Mechanical System, Applied Mechanics and Materials, Trans Tech Publications, Switzerland, 809-810, 914-919 (2015).

Ibănescu R., Bond Graphs in System Modeling in Graph Based Modelling in Engineering, Springer International Publishing Switzerland, 2017.

Karnopp D., An Approach to Derivative Causality in Bond Graph Models of Mechanical Systems, Journal of the Franklin Institute, 329, 1, 65-75 (1992).

Karnopp D., Margolis D., Rosenberg R., System Dynamics: Modeling, Simulation and Control of Mechatronic Systems, New Jersey: John Willey \& Sons Inc., 2012.

Lagnier J., Eberard D., Di Loreto M., Rémond D., Marquis-Favre W., Definition of Essential Order on Descriptor Systems and its Bond Graph Determination, ICBGM '16: Proceedings of the International Conference on Bond Graph Modeling and Simulation, July 2016, San Diego, U.S.A., 133-142.

Paynter H.M., Analysis and Design of Engineering Systems, Cambridge Massachusetts: M.I.T. Press, 1961.

Păstrăvanu O., Ibănescu R., Bond-Graph Language in Modeling and Simulation of Physical-Technical Systems, "Gheorghe Asachi”" Publishing House, Iași, Romania, 2001. 


\section{O METODĂ DE OBȚINERE A ECUAȚIILOR DIFERENTIALE DIN BOND GRAPHUL CARE CONȚINE ELEMENETE INERTiIALE ÎN CAUZALITATE DERIVATIVĂ}

\section{(Rezumat)}

Metoda bond-graph este utilizată pentru obținerea ecuațiilor care descriu dinamica sistemelor folosind analiza modului de transmitere a puterii de la sursă la elementele finale. Dacă elementele stocatoare de energie, I și C, sunt în cauzalitate integrală, atunci numărul de ecuații de stare este egal cu numărul acestor elemente. În cazul în care există și elemente stocatoare de energie în cauzalitate derivativă, sistemul de ecuații care descrie dinamica sistemului dinamic, conține un număr de ecuații diferențiale egal cu numărul de elemente stocatoare de energie aflate în cauzalitate integrală și un număr de ecuații algebrice egal cu numărul elementelor stocatoare de energie aflate în cauzalitate derivativă. Acest sistem de ecuații diferențialo-algebrice trebuie transformat într-un sistem de ecuații diferențiale. Lucrarea prezintă o nouă metodă de obținere a acestui sistem de ecuații diferențiale pentru sisteme mecanice cu un singur grad de libertate. 